ARTICLE

\title{
Water enables mild oxidation of methane to methanol on gold single-atom catalysts
}

Laihao Luo ${ }^{1,2}$, Jie Luo (1) ${ }^{1,2}$, Hongliang Li ${ }^{1 凶}$, Fangning Ren ${ }^{1}$, Yifei Zhang ${ }^{1}$, Andong Liu', Wei-Xue Li ${ }^{1 凶} \&$ Jie Zeng (1) ${ }^{1 凶}$

As a $100 \%$ atom-economy process, direct oxidation of methane into methanol remains as a grand challenge due to the dilemma between activation of methane and over-oxidation of methanol. Here, we report that water enabled mild oxidation of methane into methanol with $>99 \%$ selectivity over $A u$ single atoms on black phosphorus $\left(\mathrm{Au}_{1} / \mathrm{BP}\right)$ nanosheets under light irradiation. The mass activity of $\mathrm{Au}_{1} / \mathrm{BP}$ nanosheets reached $113.5 \mu \mathrm{mol} \mathrm{g}_{\text {catal }}{ }^{-1}$ in water pressured with 33 bar of mixed gas $\left(\mathrm{CH}_{4}: \mathrm{O}_{2}=10: 1\right)$ at $90{ }^{\circ} \mathrm{C}$ under light irradiation $(1.2 \mathrm{~W})$, while the activation energy was $43.4 \mathrm{~kJ} \mathrm{~mol}^{-1}$. Mechanistic studies revealed that water assisted the activation of $\mathrm{O}_{2}$ to generate reactive hydroxyl groups and $\bullet \mathrm{OH}$ radicals under light irradiation. Hydroxyl groups reacted with methane at Au single atoms to form water and $\mathrm{CH}_{3}{ }^{\star}$ species, followed by oxidation of $\mathrm{CH}_{3}{ }^{\star} \mathrm{via} \bullet \mathrm{OH}$ radicals into methanol. Considering the recycling of water during the whole process, we can also regard water as a catalyst.

\footnotetext{
${ }^{1}$ Hefei National Laboratory for Physical Sciences at the Microscale, CAS Key Laboratory of Strongly-Coupled Quantum Matter Physics, Key Laboratory of Surface and Interface Chemistry and Energy Catalysis of Anhui Higher Education Institutes, Department of Chemical Physics, University of Science and

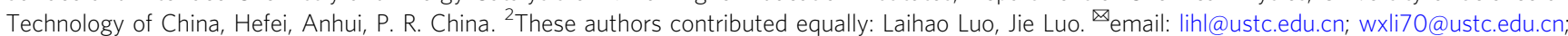
zengj@ustc.edu.cn
} 
A dvances in hydraulic fracturing technology have enabled ongoing discovery of large reserves of natural gas, which primarily contains methane ${ }^{1}$. At present, most of produced methane is burned for heating, transport, and electricitygeneration purposes. Meanwhile, methane is the second most relevant greenhouse gas emitted from anthropogenic activities, as global warming potential of methane is 25 times higher than that of $\mathrm{CO}_{2}{ }^{2}$. In this case, it is highly desired to develop efficient techniques for upgrading of methane. The current industrial route is via steam or dry reforming to generate syngas (a mixture of $\mathrm{CO}$ and $\mathrm{H}_{2}$ ), followed by Fischer-Tropsch synthesis or methanol synthesis ${ }^{3,4}$. Such route operated at high temperature $\left(>700{ }^{\circ} \mathrm{C}\right)$ not only needs huge energy input, but also leads to the deactivation of catalysts because of coking 5 . Direct conversion of methane into chemicals or liquid fuels has been achieved under mild conditions ${ }^{6-9}$. For instance, aqueous $\mathrm{Au}-\mathrm{Pd}$ colloids achieved selective oxidation of methane into methanol with $\mathrm{H}_{2} \mathrm{O}_{2}$ as an oxidant under 30 bar of $\mathrm{CH}_{4}$ at $50{ }^{\circ} \mathrm{C}^{10}$. Methane was reported to be oxidized into methanesulfonic acid by $\mathrm{SO}_{3}$ over an electrophilic initiator at $50{ }^{\circ} \mathrm{C}^{11}$. However, these processes generally involve corrosive oxidant or expensive media, such as $\mathrm{H}_{2} \mathrm{O}_{2}$, oleum, trifluoroacetic acid, and hydrobromic acid, which is not suitable for commercialization ${ }^{12-15}$.

Among direct processes, aerobic oxidation of methane into methanol is an ideal reaction with $100 \%$ atom economy (Eq. 1). The dilemma lies in activation of methane and over-oxidation of methanol ${ }^{16-18}$. Methane takes a non-polar tetrahedral structure with high dissociation energy of $\mathrm{C}-\mathrm{H}$ bond $\left(439.3 \mathrm{~kJ} \mathrm{~mol}^{-1}\right)$, rendering great difficulties for activation ${ }^{19-21}$. As methane and $\mathrm{O}_{2}$ are in singlet and triplet ground states, respectively, the direct reaction of methane with $\mathrm{O}_{2}$ in ground states is spinprohibition, which should be overcome ${ }^{22}$. Once methane is activated, the produced methanol tends to be over-oxidized into $\mathrm{CO}$ or $\mathrm{CO}_{2}$ from a thermodynamic perspective (Eqs. 1-3) 23 . Therefore, it is important but challenging to achieve highly selective oxidation of methane with $\mathrm{O}_{2}$ into methanol under ambient conditions.

$$
\begin{array}{rr}
\mathrm{CH}_{4}+0.5 \mathrm{O}_{2}=\mathrm{CH}_{3} \mathrm{OH} & \Delta \mathrm{H}_{298 \mathrm{~K}}=-126.4 \mathrm{~kJ} \mathrm{~mol}^{-1} \\
\mathrm{CH}_{4}+1.5 \mathrm{O}_{2}=\mathrm{CO}+2 \mathrm{H}_{2} \mathrm{O} & \Delta \mathrm{H}_{298 \mathrm{~K}}=-519.6 \mathrm{~kJ} \mathrm{~mol}^{-1} \\
\mathrm{CH}_{4}+2 \mathrm{O}_{2}=\mathrm{CO}_{2}+2 \mathrm{H}_{2} \mathrm{O} & \Delta \mathrm{H}_{298 \mathrm{~K}}=-802.6 \mathrm{kJmol}^{-1}
\end{array}
$$

Herein, we achieved mild oxidation of methane into methanol over $\mathrm{Au}$ single atoms on black phosphorus $\left(\mathrm{Au}_{1} / \mathrm{BP}\right)$ nanosheets with the help of water under light irradiation. Photocatalysis offers an efficient approach to drive thermodynamically non-spontaneous reactions under mild conditions ${ }^{24,25}$. We applied black phosphorus (BP) nanosheets as the support that affords broadband solar absorption for photocatalysis ${ }^{26,27}$. During methane oxidation, the mass activity of $\mathrm{Au}_{1} / \mathrm{BP}$ nanosheets was $113.5 \mu \mathrm{mol} \mathrm{g}_{\text {catal }}{ }^{-1}$ in water pressured with 33 bar of mixed gas $\left(\mathrm{CH}_{4}: \mathrm{O}_{2}=10: 1\right)$ at $90^{\circ} \mathrm{C}$ under light irradiation $(1.2 \mathrm{~W})$. The selectivity for methanol reached as high as $>99 \%$. Based on mechanistic studies, water and $\mathrm{O}_{2}$ were activated on $\mathrm{Au}_{1} / \mathrm{BP}$ nanosheets to form reactive hydroxyl groups and $\bullet \mathrm{OH}$ radicals under light irradiation. The reactive hydroxyl groups enabled mild oxidation of methane into $\mathrm{CH}_{3}{ }^{*}$ species, followed by oxidation of $\mathrm{CH}_{3}{ }^{*}$ via $\cdot \mathrm{OH}$ radicals into methanol. As water is consumed to form hydroxyl groups and produced via reaction of hydroxyl groups with methane, water is completely recycled and thus can also be regarded as a catalyst.

\section{Results and discussion}

Synthesis and characterizations of $\mathrm{Au}_{1} / \mathrm{BP}$ nanosheets. To prepare $\mathrm{Au}_{1} / \mathrm{BP}$ nanosheets, we first synthesized bulk BP through a low-pressure transport route according to the reported literature ${ }^{28}$. BP nanosheets were prepared by liquid exfoliation of bulk BP. The diameter of free-standing BP nanosheets was several hundred nanometers (Supplementary Fig. 1). As measured by atomic force microscopy, the thickness of the as-obtained nanosheet was ca. 3.0 nm (Supplementary Fig. 2). We prepared $\mathrm{Au}_{1} / \mathrm{BP}$ nanosheets by injecting $\mathrm{HAuCl}_{4}$ solution into a mixture containing ethanol and BP nanosheets with the use of a syringe pump under nitrogen protection. Figure 1a shows a high-angle annular dark-field scanning transmission electron microscopy (HAADF-STEM) image of $\mathrm{Au}_{1} / \mathrm{BP}$ nanosheets, where the Au mass loading was determined as $0.2 \mathrm{wt} \%$. The magnified HAADF-STEM image and its corresponding color-coded intensity map were shown in Fig. 1b, indicating the isolated distribution of $\mathrm{Au}$ atoms in the absence of $\mathrm{Au}$ nanoparticles (NPs). This point was further verified by HAADFSTEM images with lower magnifications (Supplementary Fig. 3). By increasing the concentration of $\mathrm{HAuCl}_{4}$ solution, we obtained $\mathrm{Au}$ NPs on BP nanosheets (denoted as Au NPs/BP nanosheets). As shown in Supplementary Figure 4, Au NPs with an average size of $6 \mathrm{~nm}$ were uniformly dispersed on BP nanosheets with a mass loading of $1.0 \mathrm{wt} \%$.

We further characterized the global structure of $\mathrm{Au}_{1} / \mathrm{BP}$ nanosheets. X-ray diffraction (XRD) patterns revealed that both $\mathrm{BP}$ and $\mathrm{Au}_{1} / \mathrm{BP}$ nanosheets were well indexed to the orthorhombic phase of BP (Supplementary Fig. 5). Especially, two intense diffraction peaks at $34.2^{\circ}$ and $52.3^{\circ}$ corresponded to (040) and (060) facets of orthorhombic BP, respectively, which are representative layered planes of BP. No patterns corresponding to Au phase were observed, in concert with the isolated dispersion of $\mathrm{Au}$ atoms. Raman spectra of $\mathrm{BP}$ and $\mathrm{Au}_{1} / \mathrm{BP}$ nanosheets show similar peaks located at 361,438 , and $466 \mathrm{~cm}^{-1}$, which were assigned to $A_{\mathrm{g}}{ }^{1}$ (outof-plane), $B_{2 \mathrm{~g}}$ (in-plane), and $A_{\mathrm{g}}{ }^{2}$ (in-plane) vibration modes of $\mathrm{BP}$, respectively (Supplementary Fig. 6)

To further determine the local environment in $\mathrm{Au}_{1} / \mathrm{BP}$ nanosheets, we measured X-ray absorption near-edge spectroscopy (XANES) and extended X-ray absorption fine structure (EXAFS). The $\mathrm{Au} L_{3}$-edge XANES profiles indicated that the Au species in $\mathrm{Au}_{1} / \mathrm{BP}$ nanosheets were in a mediate oxidation state (Fig. 1c), according to the mediate intensity for white line compared with $\mathrm{Au}$ foil and $\mathrm{Au}_{2} \mathrm{O}_{3}$. As shown in EXAFS in $R$ space (Fig. 1d), the spectrum of $\mathrm{Au}_{1} / \mathrm{BP}$ nanosheets exhibited a prominent peak at 2.33 $\AA$ from the $\mathrm{Au}-\mathrm{P}$ shell with a coordination number $(C N)$ of 2.0 (Supplementary Table 1). No other typical peaks for $\mathrm{Au}-\mathrm{Au}$ contribution at longer distances $(>2.5 \AA)$ or for $\mathrm{Au}-\mathrm{O}$ contributions at shorter distance $(<1.9 \AA)$ were observed, revealing the isolated dispersion of $\mathrm{Au}$ atoms. The peak from the $\mathrm{Au}-\mathrm{Cl}$ shell was not observed in XAFS spectra, indicating that residual $\mathrm{Cl}$ from the synthesis was absent on $\mathrm{Au}_{1} / \mathrm{BP}$ nanosheets. This result was also supported by the high-resolution X-ray photoelectron spectroscopy (XPS) spectrum which showed no signals for $\mathrm{Cl}$ (Supplementary Fig. 7). Further density functional theory (DFT) calculations were performed to establish the atomic model of $\mathrm{Au}_{1} / \mathrm{BP}$ nanosheets. To simulate $\mathrm{Au}_{1} / \mathrm{BP}$ nanosheets, we situated the $\mathrm{Au}$ single atom at the bridge $P$ sites (inset of Fig. 1d), considering thermodynamic stability and two Au-P bonds as revealed by EXAFS.

To explore the band structure of $\mathrm{BP}$ and $\mathrm{Au}_{1} / \mathrm{BP}$ nanosheets, we conducted measurements of ultraviolet-visible-near infrared (UV-vis-NIR) absorption and valence XPS. From UV-vis-NIR spectra and the corresponding Tauc plots, the bandgaps of BP and $\mathrm{Au}_{1} / \mathrm{BP}$ nanosheets were $1.45 \mathrm{eV}$ (Supplementary Fig. 8a, b). Mott-Schottky plots showed that the flat band potentials of $\mathrm{BP}$ and $\mathrm{Au}_{1} / \mathrm{BP}$ nanosheets were both $-0.35 \mathrm{~V}$ (vs RHE) (Supplementary Fig. 8c). According to valence XPS spectra, the valence band energy levels of $\mathrm{BP}$ and $\mathrm{Au}_{1} / \mathrm{BP}$ nanosheets were estimated as 1.35 and $1.31 \mathrm{eV}$ below the Fermi level, respectively (Supplementary Fig. 8d). Based on UV-vis-NIR absorption and 

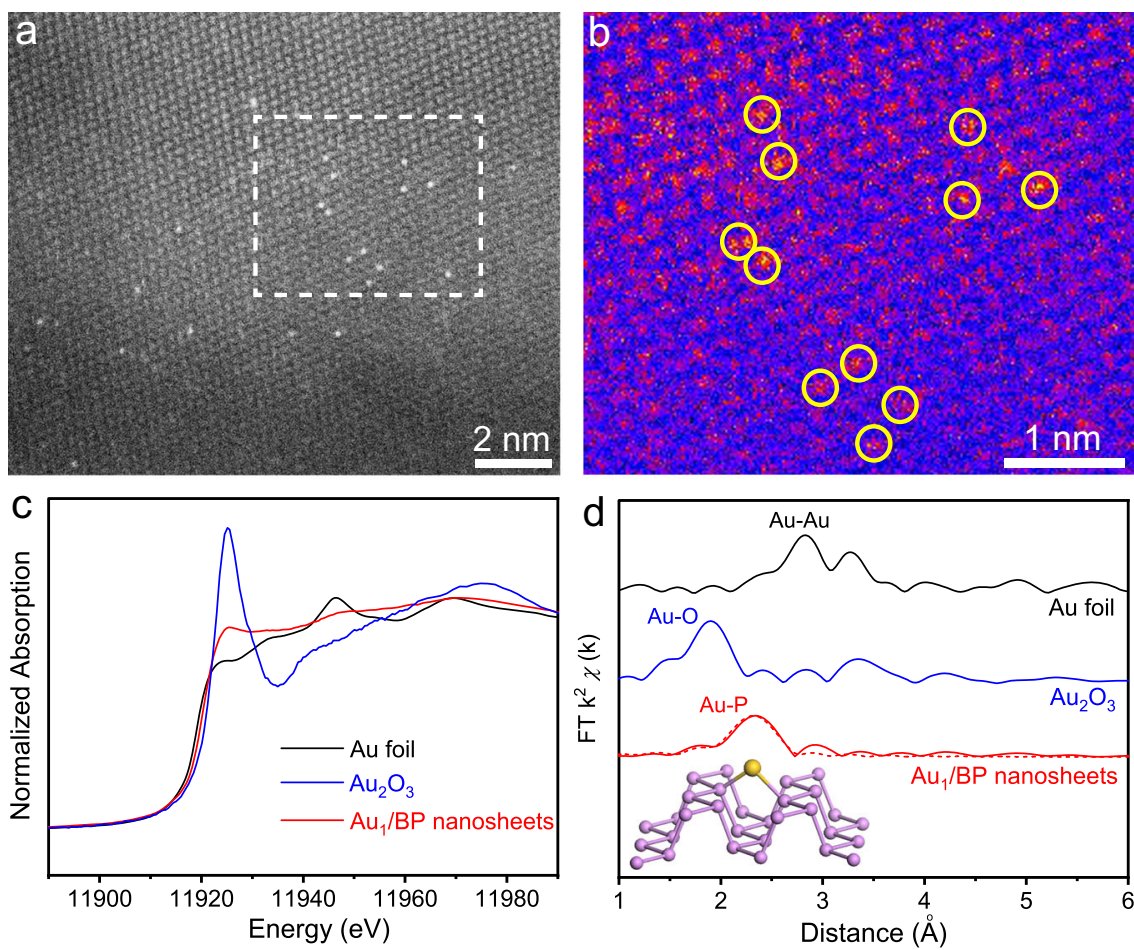

Fig. 1 Structural characterizations of $\mathbf{A u}_{1} / \mathbf{B P}$ nanosheets. a HAADF-STEM image of $A u_{1} / B P$ nanosheets. b Magnified HAADF-STEM image with colorcoded intensity. This image shows the region marked by dash box in $\mathbf{a}$. $\mathbf{c}$ XANES spectrum and $\mathbf{d}$ EXAFS spectrum of $A u_{1} / B P$ nanosheets. Au foil and $\mathrm{Au}_{2} \mathrm{O}_{3}$ were used as the references. The inset image in $\mathbf{d}$ is a structural model of $A u_{1} / \mathrm{BP}$ nanosheets. Violet and yellow spheres represent for $\mathrm{P}$ and $\mathrm{Au}$ atoms, respectively.

valence XPS spectra, the complete band structure of $\mathrm{Au}_{1} / \mathrm{BP}$ nanosheets was obtained, similar to that of BP nanosheets (Supplementary Fig. 8e). Therefore, the deposition of Au atoms on BP nanosheets led to negligible variation in the band structures of BP nanosheets. For comparison, we prepared Pt, $\mathrm{Pd}$, and $\mathrm{Rh}$ single atoms/NPs on $\mathrm{BP}$ nanosheets, which were denoted as $\mathrm{Pt}_{1} / \mathrm{BP}, \mathrm{Pd}_{1} / \mathrm{BP}, \mathrm{Rh}_{1} / \mathrm{BP}, \mathrm{Pt} \mathrm{NPs} / \mathrm{BP}, \mathrm{Pd} \mathrm{NPs} / \mathrm{BP}, \mathrm{Rh}$ NPs/BP nanosheets, respectively (Supplementary Figs. 9 and 10). The loading amounts of metal single atoms and NPs were controlled as $0.2 \mathrm{wt} \%$ and $1.0 \mathrm{wt} \%$, respectively. The dispersion of metal species in these samples was further verified by diffuse reflectance infrared Fourier transform spectroscopy (DRIFTS) experiments using $\mathrm{CO}$ as a probe molecule. Especially, DRIFTS spectra of $\mathrm{M}_{1} / \mathrm{BP}(\mathrm{M}=\mathrm{Pt}, \mathrm{Pd}$, and $\mathrm{Rh})$ nanosheets only showed the peaks for the linear adsorption of $\mathrm{CO}$, whereas, besides the peaks for the linear adsorption, the peaks for the bridge adsorption were also observed for M NPs/BP nanosheets (Supplementary Fig. 11 and Table 2).

Catalytic properties of $\mathrm{Au}_{1} / \mathrm{BP}$ nanosheets towards partial oxidation of methane. The catalytic tests were conducted in a slurry reactor with a sapphire window, which allowed the incidence of light from Xe lamp into the reactor to participate in the reaction (Supplementary Fig. 12). For a standard condition, the reaction was operated in $20 \mathrm{~mL}$ of water pressured with 33 bar of mixed gas $\left(\mathrm{CH}_{4}: \mathrm{O}_{2}=10: 1\right)$ at $90{ }^{\circ} \mathrm{C}$ under light irradiation with a light power of $1.2 \mathrm{~W}$ and irradiation area of $3.14 \mathrm{~cm}^{2}$. For BP nanosheets, the product after $2 \mathrm{~h}$ was below detection limit. As for $\mathrm{Au}_{1} / \mathrm{BP}$ nanosheets, $22.7 \mu \mathrm{mol}$ of methanol was generated without any byproducts after $2 \mathrm{~h}$ (Fig. 2a). Under the standard condition, the mass activity of $\mathrm{Au}_{1} / \mathrm{BP}$ nanosheets was $113.5 \mu \mathrm{mol} \mathrm{g}_{\text {catal }}{ }^{-1}$, whereas the turnover frequency (TOF) number was $5.6 \mathrm{~h}^{-1}$. Notably, the TOF number of $\mathrm{Au}_{1} / \mathrm{BP}$ nanosheets was higher than those of $\mathrm{Au}$ NPs/ $\mathrm{BP}, \mathrm{M}_{1} / \mathrm{BP}$, and $\mathrm{M} \mathrm{NPs} / \mathrm{BP}(\mathrm{M}=\mathrm{Pt}, \mathrm{Rh}$, and $\mathrm{Pd})$ nanosheets
(Supplementary Fig. 13). The TOF number of $\mathrm{Au}_{1} / \mathrm{BP}$ nanosheets was comparable to that of the state-of-the-art catalysts under similar reaction conditions (Supplementary Table 3). When we removed light irradiation from the standard condition, the product was below detection limit (Fig. 2a). As such, light irradiation helped drive the formation of methanol.

To further investigate the influence of light irradiation, we varied the light powers from 0.4 to $1.2 \mathrm{~W}$. As shown in Fig. $2 \mathrm{~b}$ and Supplementary Figure 14, the activity of $\mathrm{Au}_{1} / \mathrm{BP}$ nanosheets increased with the rise of light intensity at the same temperature. Notably, the activation energy $\left(E_{\mathrm{a}}\right)$ of $\mathrm{Au}_{1} /$ $\mathrm{BP}$ nanosheets was almost independent of light intensity (Fig. 2c). Especially, $E_{\mathrm{a}}$ of $\mathrm{Au}_{1} / \mathrm{BP}$ nanosheets at the power of $1.2 \mathrm{~W}$ was $43.4 \mathrm{~kJ} \mathrm{~mol}^{-1}$, approaching to that $\left(43.7 \mathrm{~kJ} \mathrm{~mol}^{-1}\right)$ at $0.8 \mathrm{~W}$ and that $\left(43.1 \mathrm{~kJ} \mathrm{~mol}^{-1}\right)$ at $0.4 \mathrm{~W}$ (Fig. $2 \mathrm{c}$ ). In addition, the reaction was determined as heterogeneous instead of homogeneous, because the use of the supernate after the reaction, $\mathrm{HAuCl}_{4}-\mathrm{H}_{3} \mathrm{PO}_{4}$, and $\mathrm{Au}(\mathrm{OH})_{3}-\mathrm{H}_{3} \mathrm{PO}_{4}$ as the catalysts gave rise to trace amounts of products (Supplementary Fig. 15). Moreover, we evaluated the wavelength-dependent apparent quantum yields (AQYs) of methanol. A high AQY of $17.4 \%$ was obtained under the irradiation of monochromatic light at 350 nm (Supplementary Fig. 16).

We further explored the influence of the solvent and reactants during partial oxidation of methane. Substitution of water with acetonitrile as the solvent from the standard condition gave rise to no products (Fig. 2a). In this case, water enables mild oxidation of methane under light irradiation. When $\mathrm{O}_{2}$ was replaced by $\mathrm{N}_{2}$ from the standard condition, leaving water as the oxidant, no detectable product was observed (Fig. 2a). As such, $\mathrm{O}_{2}$ was an indispensable oxidant, whereas only water was unable to oxidize methane under such mild reaction. In order to investigate the dependence of catalytic performance on reactants, we varied the partial pressures of $\mathrm{CH}_{4}$ and $\mathrm{O}_{2}$ at $90{ }^{\circ} \mathrm{C}$ under light irradiation. 

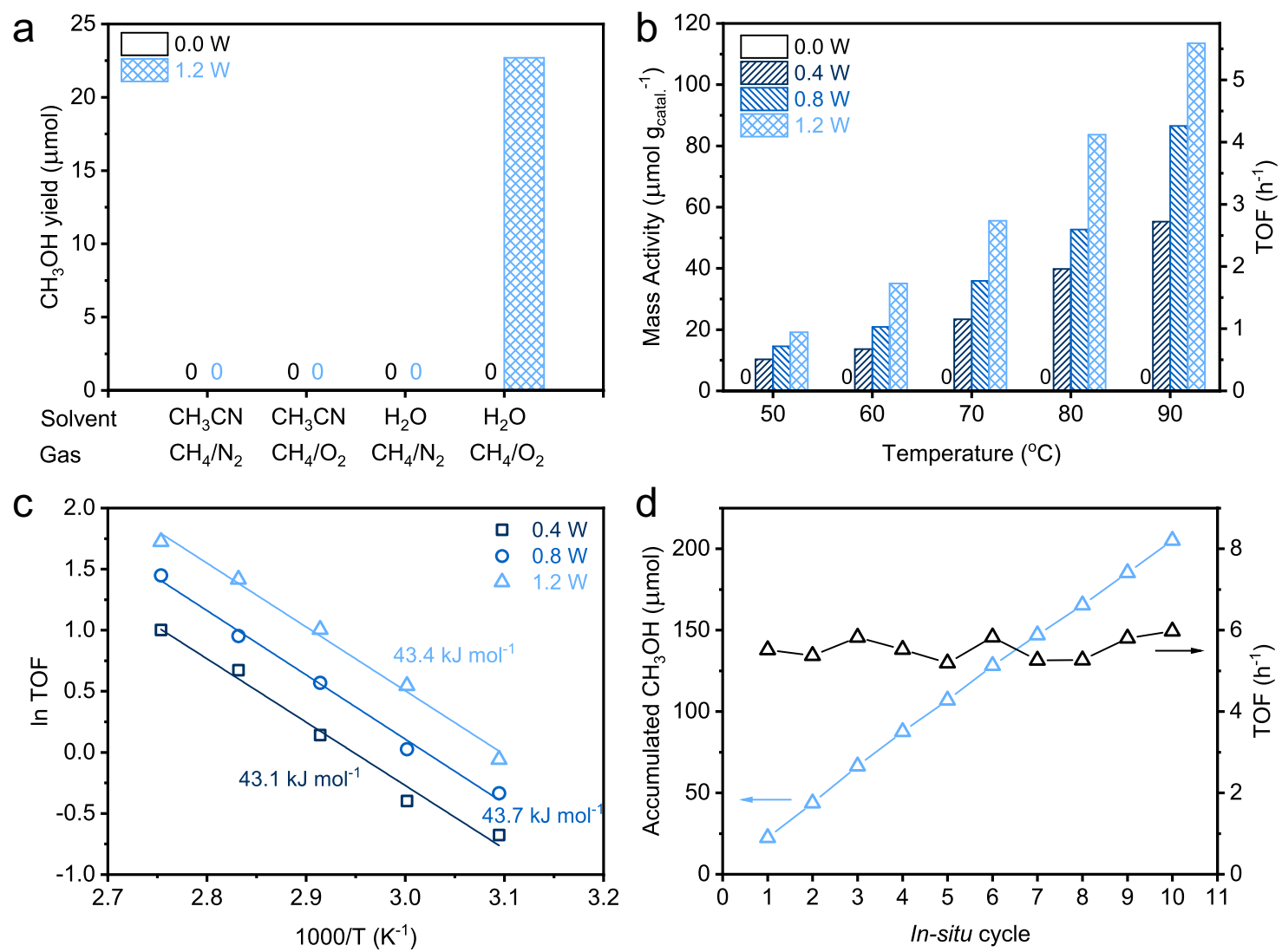

Fig. 2 Catalytic performance of $\mathbf{A u _ { 1 }} / \mathbf{B P}$ nanosheets in partial oxidation of methane. a Comparison of methanol yields under different solvents and reactants at $90^{\circ} \mathrm{C}$ for $2 \mathrm{~h}$. b Mass activities and TOF numbers in $20 \mathrm{~mL}$ of water under 33 bar $\left(\mathrm{CH}_{4}: \mathrm{O}_{2}=10: 1\right)$ at different temperatures under different light powers with an irradiation area of $3.14 \mathrm{~cm}^{2}$. c The Arrhenius plots of $\mathrm{Au}_{1} / \mathrm{BP}$ nanosheets under different light intensities. d Products and TOF numbers obtained by conducting in situ cycles. For each cycle, the catalytic reaction was operated under 33 bar $\left(\mathrm{CH}_{4}: \mathrm{O}_{2}=10: 1\right)$ at $90^{\circ} \mathrm{C}$ for $2 \mathrm{~h}(1.2 \mathrm{~W})$.

Increasing $\mathrm{CH}_{4}$ partial pressure led to the rise of conversion while keeping the selectivity for methanol above 99\% (Supplementary Fig. 17a). Increasing $\mathrm{O}_{2}$ partial pressure also increased the conversion and lowered the selectivity for methanol with the production of $\mathrm{CO}_{2}$ (Supplementary Fig. 17b). To determine whether the reaction was limited by mass transfer, we varied the stirring rates and the volumes of water. Despite of the varied stirring rates and the volumes of water, the mass activity still kept almost unchanged, indicating that the reaction kinetics was not determined by diffusion (Supplementary Fig. 18). When we used methanol as the reactants over $\mathrm{Au}_{1} / \mathrm{BP}$ nanosheets under light irradiation and 33 bar $\left(\mathrm{N}_{2}: \mathrm{O}_{2}=10: 1\right)$ at $90{ }^{\circ} \mathrm{C}$, the conversion of methanol was below detection limit. In this case, $\mathrm{Au}_{1} / \mathrm{BP}$ nanosheets were unable to catalyze the oxidation of methanol under such reaction conditions, indicating the high intrinsic selectivity for methanol.

To investigate stability of the catalysts, we tested $\mathrm{Au}_{1} / \mathrm{BP}$ nanosheets for successive in situ cycles of reaction, where catalysts were not removed from the reaction during the whole test. For each cycle, the catalytic reaction proceeded under standard conditions for $2 \mathrm{~h}$. After 10 in situ cycles ( $20 \mathrm{~h}$ in total), about $205.2 \mu \mathrm{mol}$ of methanol was generated in total with the fluctuation of TOF below 7\% (Fig. 2d). Moreover, the atomic dispersion of Au was still maintained after 10 in situ cycles, where only $\mathrm{Au}-\mathrm{P}$ bonds were observed in the absence of $\mathrm{Au}-\mathrm{Au}$ bonds or $\mathrm{Au}-\mathrm{O}$ bonds (Supplementary Fig. 19 and Table 1).

Mechanistic insights into the activation of $\mathbf{O}_{2}$. In order to investigate how water promotes methane oxidation under light irradiation, we conducted in situ DRIFTS measurements.
Background spectra were acquired after flowing with 1 bar of $\mathrm{N}_{2}$ at $150{ }^{\circ} \mathrm{C}$ for $0.5 \mathrm{~h}$, followed by cooling to $90{ }^{\circ} \mathrm{C}$. In situ DRIFTS spectrum of $\mathrm{Au}_{1} / \mathrm{BP}$ nanosheets after the treatment with $\mathrm{O}_{2}$ in the dark at $90{ }^{\circ} \mathrm{C}$ showed two peaks at 1246 and $911 \mathrm{~cm}^{-1}$, which were assigned to the stretching vibrations of $\mathrm{P}=\mathrm{O}$ and $\mathrm{P}-\mathrm{O}-\mathrm{P}$ bonds, respectively (Fig. 3a). The assignment of the peaks was supported by DFT calculations, reported literature, and isotope-labeling DRIFTS measurements (Supplementary Table 4 and Fig. 20). The peaks for $\mathrm{P}=\mathrm{O}$ and $\mathrm{P}-\mathrm{O}-\mathrm{P}$ bonds were also observed when $\mathrm{Au}_{1} / \mathrm{BP}$ nanosheets were purged by $\mathrm{O}_{2}$ under light irradiation $(1.2 \mathrm{~W})$ at $90{ }^{\circ} \mathrm{C}$ (Fig. 3b). To simulate the reaction condition in the presence of water, $\mathrm{N}_{2}$ was allowed to bubble in deionized water, followed by flowing into the cell, in order to bring the saturated water vapor into the cell, denoted as the treatment of $\mathrm{N}_{2} / \mathrm{H}_{2} \mathrm{O}$. Under the atmosphere of $\mathrm{N}_{2} / \mathrm{H}_{2} \mathrm{O}$, no peaks were observed, whenever in the dark or under light irradiation (Fig. 3a, b). As such, $\mathrm{O}_{2}$ enabled the oxidization of BP nanosheets, whereas only $\mathrm{H}_{2} \mathrm{O}$ interacted weakly with the catalyst. Compared with the circumstances of $\mathrm{O}_{2}$, the mixture of $\mathrm{O}_{2} / \mathrm{H}_{2} \mathrm{O}$ made negligible differences in the dark, but gave rise to a new peak at $3350 \mathrm{~cm}^{-1}$ for the stretching vibration of hydroxyl groups under light irradiation (Fig. 3a, b). In this case, water reacted with $\mathrm{O}_{2}$ over $\mathrm{Au}_{1} / \mathrm{BP}$ nanosheets under light irradiation, resulting in the formation of hydroxyl groups.

We further explored whether hydroxyl groups were bonded with $\mathrm{P}$ atoms or $\mathrm{Au}$ atoms. We conducted quasi situ XPS measurements after the treatment of $\mathrm{Au}_{1} / \mathrm{BP}$ nanosheets with $\mathrm{O}_{2} / \mathrm{H}_{2} \mathrm{O}$ mixed gas in the dark or under light irradiation at $90{ }^{\circ} \mathrm{C}$. $\mathrm{O} 1 \mathrm{~s}$ spectra confirmed that $\mathrm{P}-\mathrm{O}-\mathrm{P}$ and $\mathrm{P}=\mathrm{O}$ bonds were formed in the dark, whereas $\mathrm{P}-\mathrm{OH}$ bonds were generated under light irradiation (Supplementary Fig. 21a). Whenever $\mathrm{Au}_{1} / \mathrm{BP}$ 

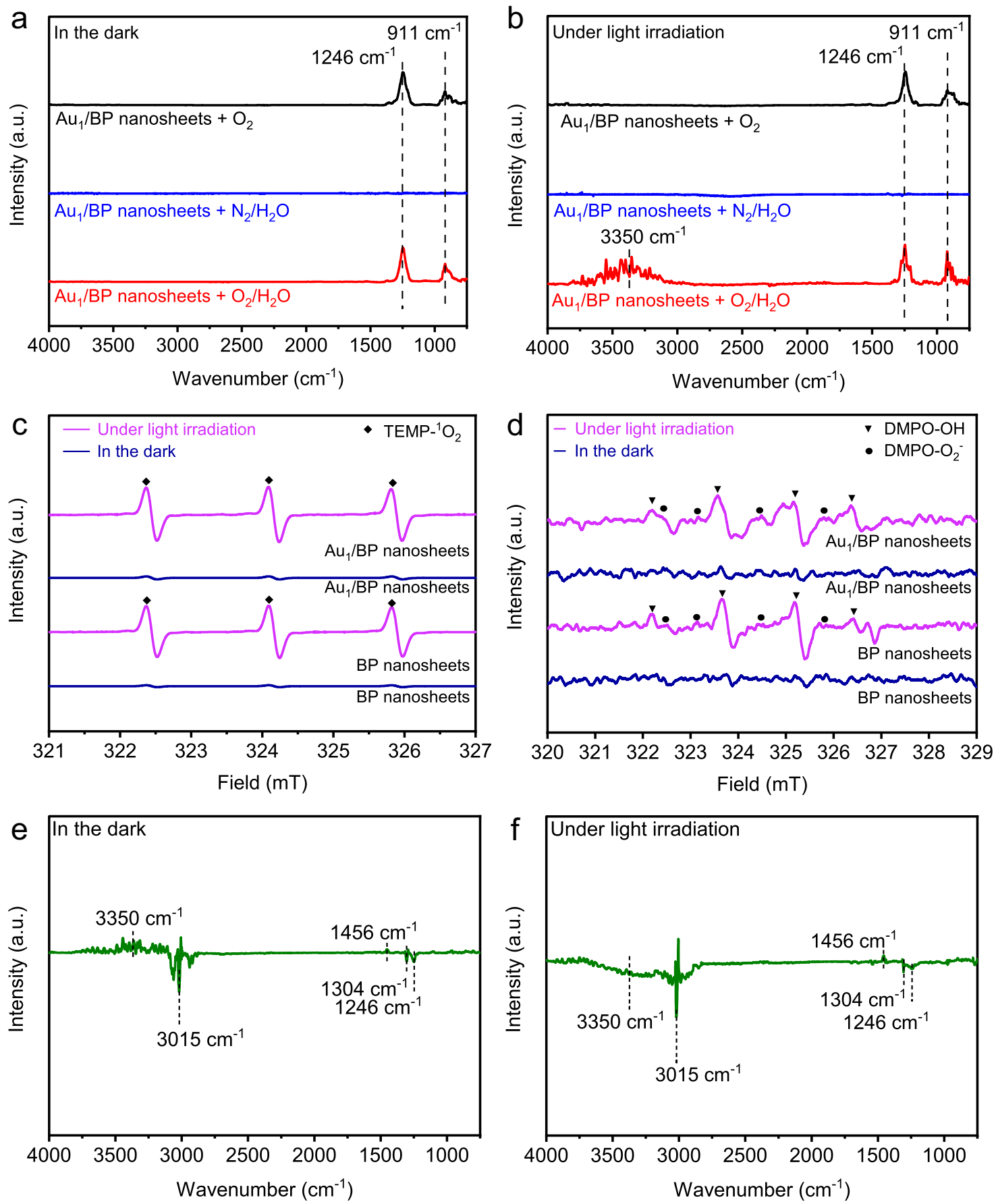

Fig. 3 Mechanistic studies. In situ DRIFTS spectra of $\mathrm{Au}_{1} / \mathrm{BP}$ nanosheets purged by 1 bar of different gases at $90^{\circ} \mathrm{C}(\mathbf{a})$ in the dark and $(\mathbf{b})$ under light irradiation. Background spectra were acquired after flowing under 1 bar of $\mathrm{N}_{2}$ with the rate of $20 \mathrm{sccm}$ at $150^{\circ} \mathrm{C}$ for $0.5 \mathrm{~h}$, followed by cooling to $90^{\circ} \mathrm{C}$. $\mathbf{c}$ In situ ESR spectra of $\mathrm{BP}$ and $\mathrm{Au}_{1} / \mathrm{BP}$ nanosheets under different conditions in the presence of TEMP. $\mathbf{d}$ In situ ESR spectra of BP and Au $/ \mathrm{BP}$ nanosheets under different conditions in the presence of DMPO. In situ DRIFTS spectra of $\mathrm{Au}_{1} / \mathrm{BP}$ nanosheets purged by 1 bar of $\mathrm{CH}_{4}$ at $90^{\circ} \mathrm{C}(\mathbf{e})$ in the dark and (f) under light irradiation. Catalysts were purged by 1 bar of $\mathrm{O}_{2} / \mathrm{H}_{2} \mathrm{O}$ at $90^{\circ} \mathrm{C}$ for $0.5 \mathrm{~h}$, followed by 1 bar of $\mathrm{N}_{2}$ at $150^{\circ} \mathrm{C}$ for $0.5 \mathrm{~h}$. Afterwards, the catalysts were purged by 1 bar of $\mathrm{CH}_{4}$ at $25^{\circ} \mathrm{C}$ for $0.5 \mathrm{~h}$ to obtain background spectra.

nanosheets were treated with $\mathrm{O}_{2} / \mathrm{H}_{2} \mathrm{O}$ in the dark or under light irradiation, Au $4 f$ spectra showed negligible difference compared with that without any treatment (Supplementary Fig. 21b). In this case, $\mathrm{Au}$ atoms were not further oxidized by $\mathrm{O}_{2} / \mathrm{H}_{2} \mathrm{O}$ in terms of the coordination with oxygen-containing groups such as $\mathrm{O}$ atoms or hydroxyl groups. To further verify this point, we conducted ${ }^{1} \mathrm{H}$ solid nuclear magnetic resonance (NMR) measurements with the reference of $\mathrm{Au}(\mathrm{OH})_{3}$. After the treatment of $\mathrm{Au}_{1} / \mathrm{BP}$ nanosheets with $\mathrm{O}_{2} / \mathrm{H}_{2} \mathrm{O}$ under light irradiation, magic angle spinning
(MAS) NMR spectrum showed no detectable signals (Supplementary Fig. 22), excluding the possibility of the adsorption of hydroxyl groups on Au atoms. Therefore, hydroxyl groups were adsorbed on $\mathrm{P}$ atoms, generating $\mathrm{P}-\mathrm{OH}$ ensembles.

Considering the short lifetime of photo-induced radicals that cannot be detected by in situ DRIFTS or quasi situ XPS, we conducted measurements of in situ electron spin resonance (ESR) spectroscopy using different trapping agents. 2,2,6,6-tetramethylpiperidine (TEMP) was selected to detect singlet $\mathrm{O}_{2}\left({ }^{1} \mathrm{O}_{2}\right)$, while 


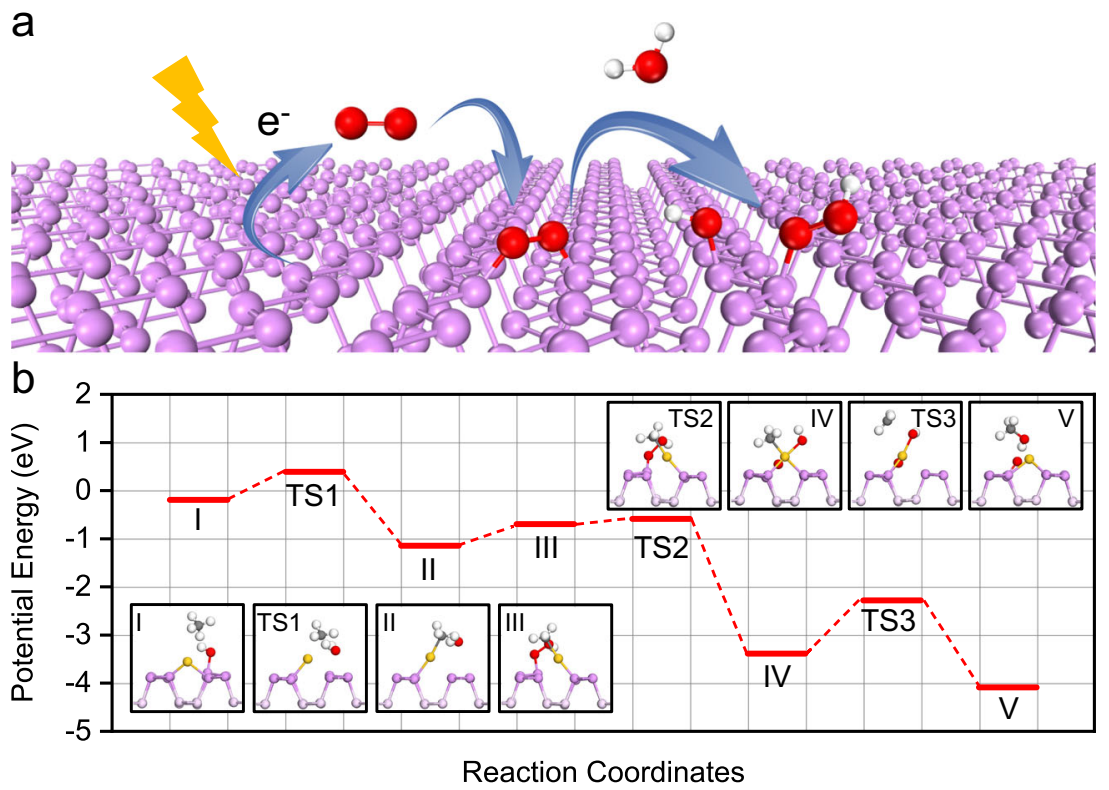

Fig. 4 DFT studies. a Schematic illustration of oxygen activation on BP nanosheets. $\mathbf{b}$ Reaction path for partial oxidation of methane over Au $\mathrm{u}_{1} / \mathrm{BP}$ nanosheets under light irradiation. The inset images show the side views of the configurations. Yellow, violet, pink, red, gray, and white spheres represent $A u$, surface $P$, subsurface $P, O, C$, and $H$ atoms, respectively.

5,5-dimethyl-1-pyrroline-N-oxide (DMPO) was selected for the detection of superoxide ions $\left(\mathrm{O}_{2}^{-}\right)$and hydroxyl radicals $(\bullet \mathrm{OH})$. As illustrated in Figure $3 c$, d, signals for ${ }^{1} \mathrm{O}_{2}, \mathrm{O}_{2}{ }^{-}$, and $\bullet \mathrm{OH}$ were all observed for both $\mathrm{BP}$ and $\mathrm{Au}_{1} / \mathrm{BP}$ nanosheets under light irradiation. Collectively, the water-promoted activation of $\mathrm{O}_{2}$ under light irradiation involves the formation of ${ }^{1} \mathrm{O}_{2}, \mathrm{O}_{2}{ }^{-}, \cdot \mathrm{OH}$, and $\mathrm{P}-\mathrm{OH}$ species.

We carried out DFT calculations to determine the adsorption configurations of dissociated $\mathrm{O}$ atoms or hydroxyl groups on $\mathrm{Au}_{1} / \mathrm{BP}$ nanosheets. The optimized configurations were obtained according to thermodynamic consideration. Supplementary Figure 23 shows the optimized adsorption configuration of two $\mathrm{O}$ atoms on $\mathrm{Au}_{1} / \mathrm{BP}$ nanosheets. Especially, one $\mathrm{O}$ atom $(\mathrm{O} 1)$ is located at the top $\mathrm{P}$ atom to form a $\mathrm{P}=\mathrm{O}$ ensemble. The other $\mathrm{O}$ atom $\left(\mathrm{O}_{2}\right)$ at the groove site is linked to two $\mathrm{P}$ atoms to form a $\mathrm{P}-\mathrm{O}-\mathrm{P}$ ensemble. These two ensembles were both observed in in situ DRIFTS spectrum (Fig. 3a). As such, the activation of $\mathrm{O}_{2}$ in the dark follows Eq. 4.

$$
\mathrm{O}_{2}+3 \mathrm{P} \rightarrow \mathrm{P}=\mathrm{O}+\mathrm{P}-\mathrm{O}-\mathrm{P}
$$

Figure 4a shows the activation of $\mathrm{O}_{2}$ under light irradiation (Supplementary Fig. 24). Especially, the electrons from the valence band of BP are excited by light irradiation to react with $\mathrm{O}_{2}$ at the triplet ground states $\left({ }^{3} \mathrm{O}_{2}\right)$, resulting in the formation of $\mathrm{O}_{2}{ }^{-}$(Eq. 5). $\mathrm{O}_{2}{ }^{-}$recombines the photo-generated holes to form the excited $\mathrm{O}_{2}$ at the singlet states, ${ }^{1} \mathrm{O}_{2}$ (Eq. 6). ${ }^{1} \mathrm{O}_{2}$ reacts with $\mathrm{H}_{2} \mathrm{O}$ to yield $\mathrm{OH}^{*}$ and $\mathrm{HOO}^{*}$ which can be split into $\cdot \mathrm{OH}$ radicals (Eqs. 7 and 8).

$$
\begin{gathered}
{ }^{3} \mathrm{O}_{2}+e^{-} \rightarrow \mathrm{O}_{2}^{-} \\
\mathrm{O}_{2}^{-}+h^{+} \rightarrow{ }^{1} \mathrm{O}_{2} \\
{ }^{1} \mathrm{O}_{2}+\mathrm{H}_{2} \mathrm{O} \rightarrow \mathrm{HOO}^{*}+\mathrm{OH}^{*} \\
\mathrm{HOO}^{*} \rightarrow \bullet \mathrm{OH}+\mathrm{O}^{*}
\end{gathered}
$$

Mechanistic insights into the oxidation of $\mathbf{C H}_{4}$. To reveal the role played by $\mathrm{P}-\mathrm{OH}$ ensembles, we carried out in situ DRIFTS measurements of $\mathrm{Au}_{1} / \mathrm{BP}$ nanosheets under $\mathrm{CH}_{4}$ after forming hydroxyl groups or not. Especially, the catalyst was purged by 1 bar of $\mathrm{O}_{2} / \mathrm{H}_{2} \mathrm{O}$ at $90{ }^{\circ} \mathrm{C}$ for $0.5 \mathrm{~h}$ in the dark to generate $\mathrm{P}=\mathrm{O}$ and $\mathrm{P}-\mathrm{O}-\mathrm{P}$ ensembles, or under light irradiation to yield $\mathrm{P}=\mathrm{O}$, $\mathrm{P}-\mathrm{O}-\mathrm{P}$, and $\mathrm{P}-\mathrm{OH}$ ensembles. Afterwards, the catalyst was purged by 1 bar of $\mathrm{CH}_{4}$ at $25^{\circ} \mathrm{C}$ for $0.5 \mathrm{~h}$ to obtain background spectra. In situ DRIFTS spectra were recorded with $\mathrm{CH}_{4}$ flow at $90{ }^{\circ} \mathrm{C}$ in the dark or under light irradiation. Notably, in in situ DRIFTS spectra, upward peaks correspond to newly appeared species, whereas downward peaks correspond to the loss of existed species.

When both the pre-treatment and in situ DRIFTS measurements were conducted in the dark, both upward and downward peaks were observed (Fig. 3e). Upward peaks included that at $3350 \mathrm{~cm}^{-1}$ for $\mathrm{P}-\mathrm{OH}$ ensembles and that at $1456 \mathrm{~cm}^{-1}$ for $\mathrm{CH}_{3}{ }^{*}$. Downward peaks included those at 3015 and $1304 \mathrm{~cm}^{-1}$ for $\mathrm{CH}_{4}{ }^{*}$, and that at $1246 \mathrm{~cm}^{-1}$ for $\mathrm{P}=\mathrm{O}$ ensembles. As such, $\mathrm{P}-\mathrm{OH}$ and $\mathrm{CH}_{3}{ }^{*}$ was generated, whereas $\mathrm{P}=\mathrm{O}$ ensembles and $\mathrm{CH}_{4}{ }^{*}$ were consumed. We propose that the reaction occurred as Eq. 9.

$$
\mathrm{CH}_{4}^{*}+\mathrm{P}=\mathrm{O} \rightarrow \mathrm{CH}_{3}^{*}+\mathrm{P}-\mathrm{OH}
$$

Considering the absence of products in the dark, $\mathrm{CH}_{3}{ }^{*}$ was unable to be further oxidized into methanol under mild condition in the dark. In other words, partial dehydrogenation of methane yielded inert $\mathrm{P}-\mathrm{OH}$ ensembles.

When both the pre-treatment and in situ DRIFTS measurements were conducted under light irradiation, the downward peaks comprised those for $\mathrm{P}-\mathrm{OH}$ ensembles, $\mathrm{P}=\mathrm{O}$ ensembles, and $\mathrm{CH}_{4}{ }^{*}$, whereas the upward peak only contained that for $\mathrm{CH}_{3}{ }^{*}$ (Fig. 3f). Considering methanol production under light irradiation, such reactive $\mathrm{P}-\mathrm{OH}$ ensembles allowed mild oxidation of methane into $\mathrm{CH}_{3}{ }^{*}$ and methanol in sequence. In addition, the in situ DRIFTS spectrum recorded in the dark after the pre-treatment under light irradiation was similar to Fig. 3f (Supplementary Fig. 25). To further identify how $\mathrm{P}-\mathrm{OH}$ ensembles participated in the reaction, we combined temperature-programmed surface reaction with mass spectroscopy (TPSR-MS) using an isotope label. Especially, we used ${ }^{18} \mathrm{O}$-labeled water $\left(\mathrm{H}_{2}{ }^{18} \mathrm{O}\right)$ and routine $\mathrm{O}_{2}$ 
$\left({ }^{32} \mathrm{O}_{2}\right)$ to pre-treat the catalyst in the dark or under light irradiation. TPSR-MS measurements were operated in the dark under $\mathrm{CH}_{4}$ when the temperature rose from 50 to $300{ }^{\circ} \mathrm{C}$. For pre-treatment in the dark, all the products were below the detection limit (Supplementary Fig. 26a, b). With regard to pre-treatment under light irradiation, four types of products were detected, including $\mathrm{CH}_{3}{ }^{18} \mathrm{OH}, \mathrm{CH}_{3}{ }^{16} \mathrm{OH}, \mathrm{H}_{2}{ }^{18} \mathrm{O}$, and $\mathrm{H}_{2}{ }^{16} \mathrm{O}$ (Supplementary Fig. 26c). Moreover, no peaks for $\mathrm{CO}_{2}$ were observed, indicating the high selectivity for methanol (Supplementary Fig. 26d). Notably, the temperature (above $200{ }^{\circ} \mathrm{C}$ ) for methanol production was much higher than that $\left(90{ }^{\circ} \mathrm{C}\right)$ during catalytic tests under light irradiation, because TPSR was conducted in the dark. In other words, methane oxidation under light irradiation follows a different path from that in the dark, despite $\mathrm{O}_{2}$ activation under light irradiation.

To investigate the mechanisms of methane oxidation under different conditions, we conducted DFT calculations. When both $\mathrm{O}_{2}$ activation and $\mathrm{CH}_{4}$ oxidation proceed in the dark, $\mathrm{CH}_{4}$ dissociates into $\mathrm{CH}_{3}{ }^{*}$ bonded to an $\mathrm{Au}$ atom and $\mathrm{H}^{*}$ stabilized by a $\mathrm{P}=\mathrm{O}$ ensemble to form a $\mathrm{P}-\mathrm{OH}$ ensemble (Supplementary Fig. 27). The reaction of $\mathrm{P}-\mathrm{OH}$ with $\mathrm{CH}_{3}{ }^{*}$ exhibits an energy difference between configurations II and TS3 of $2.18 \mathrm{eV}$, which is much higher than that $(0.42 \mathrm{eV}$, configurations II $\rightarrow \mathrm{TS} 1)$ of the recombination of $\mathrm{CH}_{3}{ }^{*}$ and $\mathrm{H}^{*}$ into $\mathrm{CH}_{4}$ (Supplementary Fig. 27). The apparent energy barrier is defined as the energy difference between the initial state and the transition state with the highest energy. In this case, the apparent energy barrier (configurations $\mathrm{I} \rightarrow \mathrm{TS} 3)$ is $2.62 \mathrm{eV}$ for the conversion of $\mathrm{CH}_{4}$ into $\mathrm{CH}_{3} \mathrm{OH}$. Therefore, in the dark, $\mathrm{P}-\mathrm{OH}$ ensembles cannot afford further oxidation of $\mathrm{CH}_{3}{ }^{*}$ into methanol over $\mathrm{Au}_{1} / \mathrm{BP}$ nanosheets, though both $\mathrm{O}_{2}$ and $\mathrm{CH}_{4}$ can be activated.

After the activation of $\mathrm{O}_{2}$ under light irradiation, we consider the oxidation of $\mathrm{CH}_{4}$ in the dark. The lack of continuous light leads to the adsorption of $\mathbf{0 H}$ into hydroxyl groups. Once two reactive hydroxyl groups are formed, one hydroxyl group reacts with $\mathrm{CH}_{4}$ to generate $\mathrm{CH}_{3}{ }^{*}$ and water. This step is the most thermodynamically favorable among different routes of $\mathrm{CH}_{4}$ activation, exhibiting an energy barrier of $0.58 \mathrm{eV}$ (Supplementary Table 5 and Fig. 28, configurations $\mathrm{I} \rightarrow \mathrm{TS} 1$ ). Afterwards, the other hydroxyl group migrates from $\mathrm{P}$ atom to $\mathrm{Au}$ atom for further oxidation of $\mathrm{CH}_{3}{ }^{*}$ (Supplementary Fig. 28, configurations $\mathrm{III} \rightarrow \mathrm{TS} 2 \rightarrow \mathrm{IV}$ ). The last step is the integration of hydroxyl groups and $\mathrm{CH}_{3}{ }^{*}$ to form methanol (Supplementary Fig. 28, configurations IV $\rightarrow \mathrm{TS} 3 \rightarrow \mathrm{V}$ ). The barrier of this step is $1.15 \mathrm{eV}$, thus determined as the rate-limiting step. Notably, the energy difference between configurations III and TS3 is as large as $1.67 \mathrm{eV}$ (Supplementary Fig. 28). The apparent energy barrier (configurations I $\rightarrow$ TS3) is $1.03 \mathrm{eV}$ for the conversion of $\mathrm{CH}_{4}$ into $\mathrm{CH}_{3} \mathrm{OH}$ (Supplementary Fig. 28).

We further focused on the reaction channel when both $\mathrm{O}_{2}$ activation and $\mathrm{CH}_{4}$ oxidation proceed under light irradiation. Upon the activation of $\mathrm{O}_{2}$, the generated hydroxyl group reacts with $\mathrm{CH}_{4}$ to form water and $\mathrm{CH}_{3}{ }^{*}$ stabilized by an $\mathrm{Au}$ atom (Fig. 4b). The breakage of $\mathrm{O}-\mathrm{O}$ bond in $\mathrm{HOO}^{*}$ generates $\cdot \mathrm{OH}$ which further co-adsorbs and reacts with $\mathrm{CH}_{3}{ }^{*}$ on the $\mathrm{Au}$ atom, exhibiting an energy barrier as low as $0.25 \mathrm{eV}$ (Fig. 4b, configurations III $\rightarrow$ TS2). Methanol is produced by the combination of $\mathrm{OH}^{*}$ and $\mathrm{CH}_{3}{ }^{*}$ on the $\mathrm{Au}$ atom with the energy barrier of $1.10 \mathrm{eV}$, which is determined as the rate-limiting step (Fig. $4 \mathrm{~b}$, configurations IV $\rightarrow \mathrm{TS} 3 \rightarrow \mathrm{V}$ ). Notably, the remaining oxygen atoms on $\mathrm{Au}_{1} / \mathrm{BP}$ nanosheets are also able to activate $\mathrm{CH}_{4}$ at $90^{\circ}$ $\mathrm{C}$ with the energy barrier of $1.19 \mathrm{eV}$, so as to complete the reaction cycle (Supplementary Fig. 29). Moreover, the apparent energy barrier for $\mathrm{CH}_{4}$ conversion into $\mathrm{CH}_{3} \mathrm{OH}$ under light irradiation (Fig. $4 \mathrm{~b}$, configurations $\mathrm{I} \rightarrow \mathrm{TS} 1$ ) is only $0.58 \mathrm{eV}$, much lower than that $(1.03 \mathrm{eV})$ in the dark. These results explain that $90{ }^{\circ} \mathrm{C}$ enables the oxidation of methane into methanol during catalytic tests under light irradiation, whereas methanol was produced above $200{ }^{\circ} \mathrm{C}$ during TPSR-MS experiments after the pre-treatment under light irradiation.

To explain the high selectivity for methanol, we investigated the processes of $\mathrm{CH}_{4}$ dehydrogenation and methanol oxidation. Except for $\mathrm{CH}_{4}$ dehydrogenation into $\mathrm{CH}_{3}{ }^{*}$, the other dehydrogenation steps $\left(\mathrm{CH}_{\mathrm{x}}{ }^{*} \rightarrow \mathrm{CH}_{\mathrm{x}-1}{ }^{*}+\mathrm{H}^{*}, x=1,2,3\right)$ are all highly endothermic (Supplementary Fig. 30). In this case, the $\mathrm{Au}$ atom stabilizes $\mathrm{CH}_{3}{ }^{*}$ to prevent deeper dehydrogenation. Moreover, we weighed the energy barriers for methanol oxidation, methanol desorption, and methane activation. Especially, the energy barrier for methanol oxidation by $\mathrm{P}-\mathrm{OH}$ species is $1.31 \mathrm{eV}$, which is higher than that (apparent energy barrier, $0.58 \mathrm{eV})$ for methane activation and that $(0.90 \mathrm{eV})$ for methanol desorption (Supplementary Fig. 31). Similar case also applies to $\mathrm{P}=\mathrm{O}$ species where the energy barriers for methanol oxidation and desorption are 1.82 and $0.83 \mathrm{eV}$, respectively (Supplementary Fig. 31). As such, the produced methanol tends to desorb from the catalyst surface and dissolve in water instead of further oxidation under mild conditions such as $90^{\circ} \mathrm{C}$ and 3 bar of $\mathrm{O}_{2}$ partial pressure. Moreover, considering the low concentration of the produced methanol and the stabilization of methanol by the polar solvent of water, the dissolved methanol is unlikely to re-adsorb on the catalyst surface for further oxidation.

In conclusion, we demonstrated that water enabled mild oxidation of methane into methanol with $>99 \%$ selectivity over $\mathrm{Au}_{1} / \mathrm{BP}$ nanosheets under light irradiation. We found that water and $\mathrm{O}_{2}$ reacted under light irradiation to generate reactive hydroxyl groups and $\bullet \mathrm{OH}$ radicals. Hydroxyl groups reacted with methane at Au single atoms to form water and $\mathrm{CH}_{3}{ }^{*}$ species. $\mathrm{CH}_{3}{ }^{*}$ species were further oxidized by $\bullet \mathrm{OH}$ radicals to generate methanol. As water is completely recycled during the whole process, it can also be regarded as a catalyst. Our findings shed light on insights into the role played by water during methane oxidation. Moreover, this work offers an effective strategy for upgrading methane at ambient condition suitable for local, on-site applications.

\section{Methods}

Catalyst preparation. In all, $500 \mathrm{mg}$ of red phosphorus, $20 \mathrm{mg}$ of $\mathrm{Sn}$, and $10 \mathrm{mg}$ of $\mathrm{SnI}_{4}$ were sealed in an evacuated Pyrex tube. The tube was heated to $650{ }^{\circ} \mathrm{C}$ with a rate of $1.4^{\circ} \mathrm{C} \mathrm{min}{ }^{-1}$ and kept at $650{ }^{\circ} \mathrm{C}$ for $5 \mathrm{~h}$, followed by cooling down to $500^{\circ} \mathrm{C}$ with a rate of $0.3^{\circ} \mathrm{C} \mathrm{min}{ }^{-1}$. After the sample, was naturally cooled down to room temperature, the product was washed with hot toluene and acetone for three times to remove the residual mineralizer. Finally, the product was dried under vacuum for further analysis. BP nanosheets were prepared by liquid exfoliation of bulk BP In detail, $200 \mathrm{mg}$ of bulk BP was dispersed in $500 \mathrm{~mL}$ of NMP. The mixture solution was then sonicated in ice water for $8 \mathrm{~h}$. Ice water was used to keep the system at relatively low temperature. Afterwards, the resultant brown suspension was centrifuged at $150 \times g$ for $10 \mathrm{~min}$ to remove the residual unexfoliated particles. The supernatant was collected by centrifugation at $11,242 \times g$ for $10 \mathrm{~min}$ and washed by a mixture of hexane, chloroform, and ethanol. After been washed for three times, BP nanosheets were dried under vacuum for further use. In a typical synthesis of $\mathrm{Au}_{1} / \mathrm{BP}$ nanosheets, $400 \mathrm{mg}$ of $\mathrm{BP}$ nanosheets was finely dispersed in $500 \mathrm{~mL}$ of ethanol under $\mathrm{N}_{2}$ protection. Then, $20 \mathrm{~mL}$ of $\mathrm{HAuCl}_{4}$ aqueous solution $(0.203 \mathrm{mM})$ was injected into the solution containing BP nanosheets through a two-channel syringe pump at room temperature for $4 \mathrm{~h}$ under $\mathrm{N}_{2}$ protection. The product was collected by centrifugation, washed three times with ethanol, and then dried under vacuum. Further ICP-AES result determined that the mass loading of $\mathrm{Au}$ was $0.2 \mathrm{wt} \%$. The syntheses of $\mathrm{Pt}_{1} / \mathrm{BP}, \mathrm{Rh}_{1} / \mathrm{BP}$, and $\mathrm{Pd}_{1} / \mathrm{BP}$ nanosheets with metal loading of $0.2 \mathrm{wt} \%$ followed the same method as that of $\mathrm{Au}_{1} / \mathrm{BP}$ nanosheets despite that $\mathrm{H}_{2} \mathrm{PtCl}_{4}, \mathrm{RhCl}_{3}$, and $\mathrm{Na}_{2} \mathrm{PdCl}_{4}$ were used as precursors, respectively. The syntheses of Au NPs/BP, Pt NPs/BP, Rh NPs/BP, and Pd NPs/BP nanosheets with metal loading of $1.0 \mathrm{wt} \%$ followed the method of $\mathrm{NaBH}_{4}$ reduction. In all, 400 $\mathrm{mg}$ of BP nanosheets were finely dispersed in $500 \mathrm{~mL}$ of ethanol under $\mathrm{N}_{2}$ protection. Then, $20 \mathrm{~mL}$ of $\mathrm{HAuCl}_{4}(1.02 \mathrm{mM}), \mathrm{H}_{2} \mathrm{PtCl}_{4}(1.03 \mathrm{mM}), \mathrm{RhCl}_{3}(1.94 \mathrm{mM})$, or $\mathrm{Na}_{2} \mathrm{PdCl}_{4}(1.88 \mathrm{mM})$ aqueous solution was added into $\mathrm{BP}$ nanosheets 
suspension and stirred for 20 min under $\mathrm{N}_{2}$ protection. In all, $8 \mathrm{~mL}$ of $\mathrm{NaBH}_{4}$ aqueous solution $(20 \mathrm{mg} / \mathrm{mL})$ was added into the mixture. After further stirring for $40 \mathrm{~min}$, the samples were collected by centrifugation, washed with ethanol for three times, and then dried under vacuum.

Catalytic tests. The partial oxidation of methane into methanol was carried out in a 180-mL stainless-steel slurry reactor (Shanghai Yanzheng Experiment Instrument Co., LTD, China). The sapphire window with an irradiation area of $3.14 \mathrm{~cm}^{-2}$ at the top of slurry reactor allows the incidence of light from Xe lamp (PLS-SXE300, PerfectLight, China) into the reactor to participate in the photocatalysis. Fullspectrum light was adopted for catalytic tests. The intensity of irradiation light was determined by a spectroradiometer (PL-MW2000, PerfectLight, China). After the addition of $20 \mathrm{~mL}$ of $\mathrm{H}_{2} \mathrm{O}$ and $200 \mathrm{mg}$ of catalysts into a Teflon inlet, the slurry reactor was pressurized with $\mathrm{CH}_{4}(30 \mathrm{bar})$ and $\mathrm{O}_{2}(3 \mathrm{bar})$ at room temperature. Then, the slurry reactor was heated to $90^{\circ} \mathrm{C}$ and kept for $2 \mathrm{~h}$ with stirring at 500 $\mathrm{rpm}$. After completion of the reaction, the slurry reactor was quickly cooled by ice water. The gas-phase was determined by gas chromatographs (Shimadzu GC-2014) equipped with a thermal conductivity detector (TCD) and a flame ionization detector (FID). The liquid phase of the reaction mixture was collected by centrifugation at $14,962 \times g$ for $5 \mathrm{~min} .20 \mu \mathrm{L}$ of DMF was introduced into $0.4 \mathrm{~mL}$ of the reaction mixture as an internal standard. In all, $100 \mu \mathrm{L}$ of the mixture was dissolved in $0.4 \mathrm{~mL}$ of DMSO- $\mathrm{d}_{6}$ to determine the product yields by ${ }^{1} \mathrm{H}$ NHR spectroscopy.

In situ cycles. For each cycle, the catalytic reaction was operated under $\mathrm{CH}_{4}(30$ bar) and $\mathrm{O}_{2}(3 \mathrm{bar})$ at $90{ }^{\circ} \mathrm{C}$ for $2 \mathrm{~h}$. After cooling down, the product in gas phase was detected by both GC-TCD and GC-FID. $0.4 \mathrm{~mL}$ of liquid products were taken for further analysis without open the reactor. Afterwards, the reactor was repressured with $\mathrm{CH}_{4}$ (30 bar) and $\mathrm{O}_{2}$ (3 bar), followed by being reheated to $90{ }^{\circ} \mathrm{C}$ and kept at this temperature for another $2 \mathrm{~h}$. The whole durability test continued for 10 in situ cycles.

XAFS measurements. XAFS spectra at $\mathrm{Au} \mathrm{L}_{3}$-edge $\left(E_{0}=11,919 \mathrm{eV}\right)$ were performed at BL14W1 beamline of Shanghai synchrotron radiation facility operated at $3.5 \mathrm{GeV}$ under "top-up" mode with a constant current of $220 \mathrm{~mA}$. The XAFS data were recorded under fluorescence mode with a $3_{2}{ }^{-}$element Ge solid state detector. The energy was calibrated according to the absorption edge of pure Au foil. Athena and Artemis codes were used to extract the data and fit the profiles. For the XANES part, the experimental absorption coefficients as a function of energies $\mu(E)$ were processed by background subtraction and normalization procedures. This process was reported as "normalized absorption". For the EXAFS part, the Fourier transformed (FT) data in $R$ space were analyzed by applying the first shell approximation or metallic $\mathrm{Au}$ model for the $\mathrm{Au}-\mathrm{P}$ or $\mathrm{Au}-\mathrm{Au}$ shell, respectively. The passive electron factors, $S_{0}^{2}$, were determined by fitting the experimental Au foil data and fixing the Au-Au $C N$ to be 12, and then fixed for further analysis of the measured samples. The parameters describing the local structure environment including $C N$, bond distance $(R)$ and Debye Waller (D.W.) factor around the absorbed atoms were allowed to vary during the fit process.

In situ DRIFTS measurements. In situ DRIFTS experiments were conducted in a cell with a Fourier transform infrared spectrometer and a liquid nitrogen cooled detector. In all, $1 \mathrm{mg}$ of $\mathrm{Au}_{1} / \mathrm{BP}$ was diluted in $200 \mathrm{mg}$ of $\mathrm{KBr}$.

As for treatments without $\mathrm{CH}_{4}$ in the dark (Fig. 3a), the background spectrum of the sample was acquired after flowing under 1 bar of $\mathrm{N}_{2}$ with the rate of $20 \mathrm{sccm}$ at $150{ }^{\circ} \mathrm{C}$ for $0.5 \mathrm{~h}$, followed by cooling to $90{ }^{\circ} \mathrm{C}$. For the treatment with $\mathrm{O}_{2}$, the sample was purged by 1 bar of $\mathrm{O}_{2}$ with the rate of $10 \mathrm{sccm}$ at $90{ }^{\circ} \mathrm{C}$ for $0.5 \mathrm{~h}$, followed by 1 bar of $\mathrm{N}_{2}$ with the rate of $20 \mathrm{sccm}$ at $90^{\circ} \mathrm{C}$ for $0.5 \mathrm{~h}$. The procedure for the treatment with $\mathrm{N}_{2}$ was similar to that for the $\mathrm{O}_{2}$ treatment, except for the use of 1 bar of $\mathrm{N}_{2}$ to replace $\mathrm{O}_{2}$. For the treatment with $\mathrm{O}_{2} / \mathrm{H}_{2} \mathrm{O}, 1$ bar of $\mathrm{O}_{2}$ was allowed to bubble in deionized water, followed by flowing into the cell, in order to bring the saturated water vapor into the cell. The sample was purged by the mixed gas containing $\mathrm{O}_{2}$ and $\mathrm{H}_{2} \mathrm{O}$ with the rate of $10 \mathrm{sccm}$ at $90^{\circ} \mathrm{C}$ for $0.5 \mathrm{~h}$, followed by 1 bar of $\mathrm{N}_{2}$ with the rate of $20 \mathrm{sccm}$ at $90{ }^{\circ} \mathrm{C}$ for $0.5 \mathrm{~h}$. The procedure for the treatment with $\mathrm{N}_{2} / \mathrm{H}_{2} \mathrm{O}$ was similar to that for the treatment with $\mathrm{O}_{2} / \mathrm{H}_{2} \mathrm{O}$, except for the use of 1 bar of $\mathrm{N}_{2}$ to replace $\mathrm{O}_{2}$.

The procedures for treatments without $\mathrm{CH}_{4}$ under light irradiation (Fig. 3b) were similar to those in the dark, except for using Xe lamp $(1.2 \mathrm{~W})$ to illuminate the cell.

As for treatments with $\mathrm{CH}_{4}$ in the dark (Fig. 3e), the sample was pre-treated under 1 bar of $\mathrm{O}_{2} / \mathrm{H}_{2} \mathrm{O}$ with the rate of $10 \mathrm{sccm}$ at $90{ }^{\circ} \mathrm{C}$ for $0.5 \mathrm{~h}$ to generate $\mathrm{P}=\mathrm{O}$ and $\mathrm{P}-\mathrm{O}-\mathrm{P}$ ensembles. Afterwards, the sample was purged by 1 bar of $\mathrm{CH}_{4}$ with the rate of $10 \mathrm{sccm}$ at $25^{\circ} \mathrm{C}$ for $0.5 \mathrm{~h}$ to obtain background spectra. In situ DRIFTS spectrum was recorded under 1 bar of $\mathrm{CH}_{4}$ with the rate of $10 \mathrm{sccm}$ at $90{ }^{\circ} \mathrm{C}$ in the dark.

The procedure for the treatment with $\mathrm{CH}_{4}$ under light irradiation (Fig. 3f) was similar to that in the dark, except for using Xe lamp $(1.2 \mathrm{~W})$ to illuminate the cell. Notably, the pre-treatment with $\mathrm{O}_{2} / \mathrm{H}_{2} \mathrm{O}$ under light irradiation aimed at yielding $\mathrm{P}=\mathrm{O}, \mathrm{P}-\mathrm{O}-\mathrm{P}$, and $\mathrm{P}-\mathrm{OH}$ ensembles.

DRIFTS measurements using $\mathbf{C O}$ as a probe molecule. The background spectrum of the sample was acquired after flowing under 1 bar of $\mathrm{N}_{2}$ with the rate of $20 \mathrm{sccm}$ at $150{ }^{\circ} \mathrm{C}$ for $0.5 \mathrm{~h}$, followed by cooling to $25^{\circ} \mathrm{C}$. Then, 1 bar of $10 \% \mathrm{CO} / \mathrm{Ar}$ with the rate of $10 \mathrm{sccm}$ was allowed to flow into the cell for $20 \mathrm{~min}$. 1 bar of $\mathrm{N}_{2}$ with the rate of $20 \mathrm{sccm}$ was used to purge out the gaseous CO from the sample cell so that the chemically adsorbed $\mathrm{CO}$ species on the samples could be detected.

In situ ESR measurements. $\mathrm{Au}_{1} / \mathrm{BP}$ nanosheets were dispersed in water presaturated with $\mathrm{CH}_{4}$ and $\mathrm{O}_{2}$ to detect possible radicals $\left(4 \mathrm{~g} \mathrm{~L}^{-1}\right)$. As for the ${ }^{1} \mathrm{O}_{2}$ trapping-ESR tests, $50 \mu \mathrm{L}$ of aqueous suspension of samples was mixed with $500 \mu \mathrm{L}$ of 2,2,6,6-tetramethylpiperidine $(50 \mathrm{mM})$ solution. After being illuminated for 1 min, the mixture was characterized using an ESR spectrometer (JEOL JES-FA200) at room temperature. As for the $\mathrm{O}_{2}{ }^{-}$and $\bullet \mathrm{OH}$ trapping-ESR tests, similar procedures were adopted except the use of 5,5-dimethyl-1-pyrroline-N-oxide (DMPO) as the spin-trapping agent.

TOF calculation. The TOF numbers were calculated based following equation (equation 10):

$$
\begin{gathered}
\text { TOF } \\
=\left(n_{\mathrm{CH} 3 \mathrm{OH}}+n_{\mathrm{CO} 2}\right) /\left(t \times n_{\text {surface }}\right) \\
=\left(n_{\mathrm{CH} 3 \mathrm{OH}}+n_{\mathrm{CO} 2}\right) /\left(t \times \delta \times n_{\text {metal }}\right) \\
=\left(n_{\mathrm{CH} 3 \mathrm{OH}}+n_{\mathrm{CO} 2}\right) /\left(t \times \delta \times m_{\text {cat }} \times w / \mu_{\text {metal }}\right)
\end{gathered}
$$

In these equations, $n_{\mathrm{CH} 3 \mathrm{OH}}$ represents the mole of produced $\mathrm{CH}_{3} \mathrm{OH}$ molecules. $t$ is the reaction time. $n_{\text {surface }}$ is the mole of surface metal atoms. $\delta$ is the molar ratio of surface atom. $n_{\text {metal }}$ is the mole of total metal atoms. $m_{\text {cat }}$ is the mass of the catalysts. $w$ is the mass loading of the catalysts. $\mu_{\text {metal }}$ is the atomic mass. For single atoms, $\delta=100 \%$. For NPs, $\delta$ was calculated using the following equations (equations $11-13)$ given by Vannice 29 .

$$
\begin{gathered}
\delta=6 \times 10^{7} \times\left(V_{\text {metal }} / A_{\text {metal }}\right) \times\left(1 / d_{\text {metal }}\right) \times 100 \% \\
V_{\text {metal }}=\mu_{\text {metal }} /\left(\rho_{\text {metal }} \times N_{A}\right) \\
A_{\text {metal }}=1 / n_{s}
\end{gathered}
$$

where $V_{\text {metal }}$ is the bulk atomic volume of the metals $\left(\mathrm{cm}^{3}\right), A_{\text {metal }}$ is the area of an atom $\left(\mathrm{cm}^{2}\right)$, and $d$ is the metal particle size in $\mathrm{nm} . \mu_{\text {metal }}$ is the atomic mass, $\rho$ is the bulk density, and $N_{\mathrm{A}}$ is Avogadro's number. $n_{\mathrm{s}}$ is the average site density. The $n_{\mathrm{s}}$ of $\mathrm{Au}, \mathrm{Pt}$, Rh, Pd were $1.2 \times 10^{15}, 1.3 \times 10^{15}, 1.3 \times 10^{15}$, and $1.3 \times 10^{15} \mathrm{~cm}^{-2}$, respectively ${ }^{30}$. Thus $A_{\text {metal }}$ were calculated as $8.7 \times 10^{-16}, 8.0 \times 10^{-16}, 7.5 \times 10^{-16}$, $7.9 \times 10^{-16} \mathrm{~cm}^{2}$. The values of $V_{\text {metal }}$ were calculated as $1.7 \times 10^{-23}, 1.5 \times 10^{-23}$, $1.4 \times 10^{-23}, 1.5 \times 10^{-23} \mathrm{~cm}^{3}$ for $\mathrm{Au}, \mathrm{Pt}, \mathrm{Rh}$, and $\mathrm{Pd}$, respectively. The average sizes $\left(d_{\text {metal }}\right)$ of NPs were measured to be $6 \mathrm{~nm}, 5 \mathrm{~nm}, 4 \mathrm{~nm}$, and $6 \mathrm{~nm}$ for $\mathrm{Au}, \mathrm{Pt}, \mathrm{Rh}$, and Pd, respectively, based on TEM images. Therefore, the values of $\delta$ were calculated to be $19.5 \%, 22.6 \%, 27.5 \%$, and $18.6 \%$ for $\mathrm{Au}, \mathrm{Pt}, \mathrm{Rh}$, and $\mathrm{Pd}$, respectively. The TOF numbers of $\mathrm{Au}_{1} / \mathrm{BP}, \mathrm{Pt}_{1} / \mathrm{BP}, \mathrm{Rh}_{1} / \mathrm{BP}, \mathrm{Pd}_{1} / \mathrm{BP}, \mathrm{Au}$ NPs/BP, Pt NPs/BP, Rh $\mathrm{NPs} / \mathrm{BP}$, and $\mathrm{Pd} \mathrm{NPs} / \mathrm{BP}$ nanosheets were calculated as 5.6, 4.5, 1.1, 3.2, 3.3, 0.8 , 0.2 , and $2.1 \mathrm{~h}^{-1}$, respectively.

Conversion calculation. The conversion was calculated based following equation (equation 14):

$$
\text { Conversion }=\left(n_{\mathrm{CH} 3 \mathrm{OH}}+n_{\mathrm{CO} 2}\right) / n_{\mathrm{CH} 4} \times 100 \%
$$

The amount of $\mathrm{CH}_{4}$ charged into the reactor is calculated from 30 bar of $\mathrm{CH}_{4}$ at room temperature. The volume of gas is $160 \mathrm{~mL}$, which corresponds to $193.6 \mathrm{mmol}$ $\mathrm{CH}_{4}$. The conversion after $2 \mathrm{~h}$ was calculated as $0.01 \%$. We chose a low conversion in order to measure the kinetic parameters such as the reaction rate, TOF, and $E_{\mathrm{a}}$, because the temperature, pressure, and concentrations can be regarded as constant throughout the reactor ${ }^{31}$.

AQY measurements. The apparent quantum yields (AQY) were measured under the irradiation of monochromatic lights at $350,380,450,500,550,600,650$, and $765 \mathrm{~nm}$ using band-pass filters. The irradiation area was $3.14 \mathrm{~cm}^{2}$. The intensities of irradiation light was determined to be $2.1,4.2,21.9,15.6,19.3,23.9,26.0$, and $23.9 \mathrm{~mW} \cdot \mathrm{cm}^{-2}$ for $350,380,450,500,550,600,650$, and $765 \mathrm{~nm}$, respectively. The formation of one methanol molecule only consumes one photo-generated electron during the generation of reactive hydroxyl groups and $\bullet \mathrm{OH}$ radicals. The AQY was calculated according to the following equation (equation 15):

$$
\begin{aligned}
\mathrm{AQY} & =1 \times N_{\mathrm{CH} 3 \mathrm{OH}} / N_{\text {photons }} \times 100 \% \\
& =1 \times N_{\mathrm{CH} 3 \mathrm{OH}} \times N_{A} /[W \times A \times t /(h \times v)] \times 100 \%
\end{aligned}
$$

$N_{\mathrm{CH} 3 \mathrm{OH}}$ and $N_{\text {photons }}$ represent the number of formed $\mathrm{CH}_{3} \mathrm{OH}$ and the number of incident photons. $v, W, A$, and $t$ are the incident light frequency, intensity, irradiation area and time, respectively. $N_{\mathrm{A}}$ and $h$ are the Avogadro's constant and Planck constant, respectively. The AQYs were calculated to be $17.4 \%, 8.7 \%, 1.3 \%, 0.9 \%, 1.0 \%$, $0.6 \%, 0.4 \%$, and $0.4 \%$ for $350,380,450,500,550,600,650$, and $765 \mathrm{~nm}$, respectively.

TPSR-MS measurements. In all, $100 \mathrm{mg}$ of $\mathrm{Au}_{1} / \mathrm{BP}$ nanosheets were pre-treated by being immersed in $5 \mathrm{~mL}{ }^{18} \mathrm{O}$-labeled water $\left(\mathrm{H}_{2}{ }^{18} \mathrm{O}\right)$ under $\mathrm{O}_{2}\left({ }^{32} \mathrm{O}_{2}\right)$ flow in 
the dark or under light irradiation $(1.2 \mathrm{~W})$ at $90^{\circ} \mathrm{C}$ for $0.5 \mathrm{~h}$. The treated samples were dried under vacuum, followed by being loaded into the quartz tube for further measurement. For TPSR-MS measurements, the pre-treated samples were heated in helium with a gas-flow rate of $20 \mathrm{~mL} \mathrm{~min}^{-1}$ at $200{ }^{\circ} \mathrm{C}$ for $1 \mathrm{~h}$. After cooling down to $50{ }^{\circ} \mathrm{C}$, the gas was switched to $10 \% \mathrm{CH}_{4} / \mathrm{Ar}(\mathrm{v} / \mathrm{v}$ ) with a gas-flow rate of $20 \mathrm{~mL} \mathrm{~min}^{-1}$. Mass spectral responses were collected from 50 to $300{ }^{\circ} \mathrm{C}$ at $5{ }^{\circ} \mathrm{C} \mathrm{min}^{-1}$. We detected the mass numbers $(\mathrm{m} / \mathrm{z})$ of 33 for $\mathrm{CH}_{3}{ }^{18} \mathrm{OH}$, 31 for $\mathrm{CH}_{3}{ }^{16} \mathrm{OH}, 19$ for $\mathrm{H}_{2}{ }^{18} \mathrm{O}, 17$ for $\mathrm{H}_{2}{ }^{16} \mathrm{O}, 48$ for $\mathrm{C}^{18} \mathrm{O}_{2}, 46$ for $\mathrm{C}^{18} \mathrm{O}^{16} \mathrm{O}$, and 44 for $\mathrm{C}^{16} \mathrm{O}_{2}$.

DFT calculations. Spin-polarized DFT calculations were performed through Vienna ab initio simulation package ${ }^{32,33}$. The electron-ion interaction was described via the projector augmented wave method $^{34}$. The exchange-correlation interaction was described via the optB86b-vdW functional ${ }^{35}$. The plane-wave basis set was used to solve the Kohn-Sham equations, whereas the kinetic energy cutoff was $400 \mathrm{eV}$. In our calculations, a $12-\AA ̊$ vacuum layer and a single layer of BP with $(3 \times 3)$ supercells were constructed to simulate $\mathrm{Au}_{1} / \mathrm{BP}$ nanosheets. All the atoms were relaxed during the structure optimization until the maximum force on any ion was less than $0.02 \mathrm{eV}^{-1}$. The $(4 \times 3 \times 1) k$-point mesh was used to sample the Brillouin zone. The climbing-image nudged elastic band method was used to identify the transition states until the maximum force on any ion was less than $0.05 \mathrm{eV} \AA^{-136}$

\section{Data availability}

The data that support the findings of this study are available from the corresponding author upon reasonable request.

\section{Code availability}

The code is available from the corresponding author upon reasonable request.

Received: 28 June 2020; Accepted: 12 January 2021;

Published online: 22 February 2021

\section{References}

1. McFarland, E. Unconventional chemistry for unconventional natural gas. Science 338, 341-342 (2012).

2. Nisbet, E. G., Dlugokencky, E. J. \& Bousquet, P. Methane on the rise-again Science 343, 493-495 (2014).

3. Schüth, F. Making more from methane. Science 363, 1282-1283 (2019).

4. Tang, P., Zhu, Q., Wu, Z. \& Ma, D. Methane activation: the past and future. Energy Environ. Sci. 7, 2580-2591 (2014).

5. Mattos, L. V., Jacobs, G., Davis, B. H. \& Noronha, F. B. Production of hydrogen from ethanol: review of reaction mechanism and catalyst deactivation. Chem. Rev. 112, 4094-4123 (2012).

6. Shan, J., Li, M., Allard, L. F., Lee, S. \& Flytzani-Stephanopoulos, M. Mild oxidation of methane to methanol or acetic acid on supported isolated rhodium catalysts. Nature 551, 605-608 (2017).

7. Jin, Z. et al. Hydrophobic zeolite modification for in situ peroxide formation in methane oxidation to methanol. Science 367, 193-197 (2020).

8. Xie, J. et al. Highly selective oxidation of methane to methanol at ambient conditions by titanium dioxide-supported iron species. Nat. Catal. 1, 889-896 (2018).

9. Ikuno, T. et al. Methane oxidation to methanol catalyzed by $\mathrm{Cu}-\mathrm{Oxo}$ clusters stabilized in NU-1000 metal-organic framework. J. Am. Chem. Soc. 139, 10294-10301 (2017)

10. Agarwal, N. et al. Aqueous Au-Pd colloids catalyze selective $\mathrm{CH}_{4}$ oxidation to $\mathrm{CH}_{3} \mathrm{OH}$ with $\mathrm{O}_{2}$ under mild conditions. Science 358, 223-227 (2017)

11. Díaz-Urrutia, C. \& Ott, T. Activation of methane to $\mathrm{CH}_{3}{ }^{+}$: a selective industrial route to methanesulfonic acid. Science 363, 1326 (2019).

12. Hammond, C. et al. Direct catalytic conversion of methane to methanol in an aqueous medium by using copper-promoted Fe-ZSM-5. Angew. Chem. Int. Ed. 51, 5129-5133 (2012).

13. Zimmermann, T., Soorholtz, M., Bilke, M. \& Schüth, F. Selective methane oxidation catalyzed by platinum salts in oleum at turnover frequencies of large-scale industrial processes. J. Am. Chem. Soc. 138 12395-12400 (2016).

14. Muehlhofer, M., Strassner, T. \& Herrmann, W. A. New catalyst systems for the catalytic conversion of methane into methanol. Angew. Chem. Int. Ed. 41, 1745-1747 (2002).

15. Paunovic, V., Zichittella, G., Moser, M., Amrute, A. P. \& Perez-Ramirez, J. Catalyst design for natural-gas upgrading through oxybromination chemistry. Nat. Chem. 8, 803-809 (2016).
16. Ravi, M., Ranocchiari, M. \& van Bokhoven, J. A. The direct catalytic oxidation of methane to methanol-a critical assessment. Angew. Chem. Int. Ed. 56, 16464-16483 (2017)

17. Ravi, M. et al. Misconceptions and challenges in methane-tomethanol over transition-metal-exchanged zeolites. Nat. Catal. 2, 485-494 (2019).

18. Liu, Z. et al. Water-promoted interfacial pathways in methane oxidation to methanol on a $\mathrm{CeO}_{2}-\mathrm{Cu}_{2} \mathrm{O}$ catalyst. Science 368, 513-517 (2020).

19. Schwach, P., Pan, X. \& Bao, X. Direct conversion of methane to value-added chemicals over heterogeneous catalysts: challenges and prospects. Chem. Rev. 117, 8497-8520 (2017).

20. Zhang, C. J. \& Hu, P. The possibility of single $\mathrm{C}-\mathrm{H}$ bond activation in $\mathrm{CH}_{4}$ on a $\mathrm{MoO}_{3}$-supported Pt catalyst: a density functional theory study. J. Chem. Phys. 116, 4281-4285 (2002).

21. Akri, M. et al. Atomically dispersed nickel as coke-resistant active sites for methane dry reforming. Nat. Commun. 10, 5181 (2019).

22. Montemore, M. M., van Spronsen, M. A., Madix, R. J. \& Friend, C. M. $\mathrm{O}_{2}$ activation by metal surfaces: implications for bonding and reactivity on heterogeneous catalysts. Chem. Rev. 118, 2816-2862 (2018).

23. Haynes, W. M. CRC Handbook of Chemistry and Physics. 91st edn (CRC, 2010).

24. Zhou, Y., Zhang, L. \& Wang, W. Direct functionalization of methane into ethanol over copper modified polymeric carbon nitride via photocatalysis. Nat. Commun. 10, 506 (2019).

25. Murcia-López, S. et al. Controlled photocatalytic oxidation of methane to methanol through surface modification of beta zeolites. ACS Catal. 7, 2878-2885 (2017).

26. Gusmão, R., Sofer, Z. \& Pumera, M. Black phosphorus rediscovered: from bulk material to monolayers. Angew. Chem. Int. Ed. 56, 8052-8072 (2017).

27. Carvalho, A. et al. Phosphorene: from theory to applications. Nat. Rev. Mater. 1, 16061 (2016).

28. Luo, Z. et al. Anisotropic in-plane thermal conductivity observed in few-layer black phosphorus. Nat. Commun. 6, 8572 (2015).

29. Vannice, M. A. Kinetics of Catalytic Reactions, 23-33 (Springer, 2005).

30. Bergeret, G. \& Gallezot, P. Handbook of Heterogeneous Catalysis. G. Ertl, H. Knözinger and J. Weitkamp (eds.) Vol. 2, 439 (Wiley-VCH, 1997)

31. Zhang, M., Wang, M., Xu, B. \& Ma, D. How to measure the reaction performance of heterogeneous catalytic reactions reliably. Joule 3, 2876-2883 (2019).

32. Kresse, G. \& Furthmüller, J. Efficient iterative schemes for ab initio totalenergy calculations using a plane-wave basis set. Phys. Rev. B: Condens. Matter Mater. Phys. 54, 11169-11186 (1996).

33. Kresse, G. \& Furthmüller, J. Efficiency of ab-initio total energy calculations for metals and semiconductors using a plane-wave basis set. Comput. Mater. Sci. 6, 15-50 (1996).

34. Kresse, G. \& Joubert, D. From ultrasoft pseudopotentials to the projector augmented-wave method. Phys. Rev. B: Condens. Matter Mater. Phys. 59, $1758-1775$ (1999).

35. Klimeš, J., Bowler, D. R. \& Michaelides, A. Van der Waals density functionals applied to solids. Phys. Rev. B 83, 195131 (2011).

36. Henkelman, G. \& Jónsson, H. Improved tangent estimate in the nudged elastic band method for finding minimum energy paths and saddle points. J. Chem. Phys. 113, 9978-9985 (2000).

\section{Acknowledgements}

This work was supported by National Key Research and Development Program of China (2019YFA0405600), National Science Fund for Distinguished Young Scholars (21925204), NSFC (U19A2015, 91645202, and 91945302), Key Technologies R\&D Program of China (2017YFB0602205, 2018YFA0208603), Key Research Program of Frontier Sciences of the CAS (QYZDB-SSW-SLH017), China Postdoctoral Science Foundation (2020M682007), China Postdoctoral Program for Innovative Talents (BX20200323), Fundamental Research Funds for the Central Universities, USTC Research Funds of the Double First-Class Initiative (YD2340002002), and Provincial Key Research and Development Program of Anhui (202004a05020074). This work was partially carried out at the USTC Center for Micro and Nanoscale Research and Fabrication. The Supercomputing Center of University of Science and Technology of China is acknowledged for numerical calculations.

\section{Author contributions}

L.L. and J.L. equally contributed to this work. L.L., H.L., and J.Z. designed the studies and wrote the paper. L.L., H.L., and F.R. synthesized catalysts. L.L. H.L., and Y.Z. performed catalytic tests. J.L. and W.L. performed DFT calculations. L.L. H.L., Y.Z., and A.L. conducted DRIFTS and XPS measurements. L.L. and H.L. conducted XAFS measurements. L.L. and A.L. conducted TPSR-MS experiments. All authors discussed the results and commented on the manuscript. 


\section{Competing interests}

The authors declare no competing interests.

\section{Additional information}

Supplementary information The online version contains supplementary material available at https://doi.org/10.1038/s41467-021-21482-z.

Correspondence and requests for materials should be addressed to H.L., W.-X.L. or J.Z.

Peer review information Nature Communications thanks Botao Qiao, Hai Xiao, and other, anonymous, reviewers for their contributions to the peer review of this work.

Reprints and permission information is available at http://www.nature.com/reprints

Publisher's note Springer Nature remains neutral with regard to jurisdictional claims in published maps and institutional affiliations. (c) (P) Open Access This article is licensed under a Creative Commons Attribution 4.0 International License, which permits use, sharing, adaptation, distribution and reproduction in any medium or format, as long as you give appropriate credit to the original author(s) and the source, provide a link to the Creative Commons license, and indicate if changes were made. The images or other third party material in this article are included in the article's Creative Commons license, unless indicated otherwise in a credit line to the material. If material is not included in the article's Creative Commons license and your intended use is not permitted by statutory regulation or exceeds the permitted use, you will need to obtain permission directly from the copyright holder. To view a copy of this license, visit http://creativecommons.org/ licenses/by/4.0/.

(C) The Author(s) 2021 